\title{
The Development of the Assessment Methods of the Organizational Potential of the Institutions of High Education
}

\author{
Sergey Mikhailovich Vasin ${ }^{1}$, Leyla Ayvarovna Gamidullaeva ${ }^{1}$ \& Penza State University ${ }^{1}$ \\ ${ }^{1}$ Penza, Krasnaya Street, 40, Russian Federation \\ Correspondence: Sergey Mikhailovich Vasin, Penza, 440026, Krasnaya Street, 40, Russian Federation. E-mail: \\ gamidullaeva@gmail.com
}

Received: August 28, 2014 Accepted: September 12, 2014 Online Published: November 27, 2014

doi:10.5539/ass.v10n24p285

URL: http://dx.doi.org/10.5539/ass.v10n24p285

\begin{abstract}
In strategic documents of the Russian Federation the development of education is considered as one of the objectives of socio-economic development of the country. Nowadays, despite the considerable interest of the scientific community to the problem of the effectiveness of higher education institutions, there are no scientific studies to enable a comprehensive approach to the assessment of the organizational capacity of universities. The purpose of this article is to solve the most important managerial task through the development of a methodology for assessing the institutional capacity of higher education institutions. The article contains a critical analysis of the approaches to the assessment of the effectiveness carried out in practice in the institutions of higher education.

It was settled that organizational potential is the basic element of the mechanism, which enables to enhance the operating benefits of institutions of high education. The author's approach to the organizational potential structuring of the university is suggested. The organizational potential assessment method enables to take into account the cumulative effect of many factors on the operating benefits of the university management. The functioning of the proposed methods in the managerial practice will favour accumulation of the organizational potential of the universities and improve the efficiency of their work. The study developed the methods with the following characteristics: firstly, it provides the possibility of considering the institution of high education as a subject of market relations and the use of many factors that can be later supplemented in calculation; secondly, there is a possibility to take into account territorial characteristics of the regions in which universities operate when calculating the effectiveness of universities; thirdly, the technique allows not only to determine the level of private indicators characterizing the efficiency of organizational potential, but also to identify existing reserves of development, to identify key factors that have the greatest impact on the effectiveness of the university activities, united on a territorial basis, and to compare the objects of study.
\end{abstract}

Keywords: university, organizational potential, university management, assessment methods, operating benefits

\section{Introduction}

Today we can confirm that Russia has finally taken the road of innovative market economy and the integration into the global economic system. In this regard, there is urgent necessity to work out management concepts of the key areas of socio-economic life, which form the prospects of the efficient and sustainable development of the country hereafter. One of the most important spheres in this regard is higher education and training-the key link in the cycle "education-a technological breakthrough-economic growth-well-being." In policy documents of the Russian Federation in the field of economics, innovation, national security the development of education is considered as one of the tasks of socio-economic development of the state.

It is indisputable that under present conditions the problem of the management and strategy formation becomes essential. The attained level of the university efficiency depends not only on external factors (regulatory framework, public support, etc.), but also on the level of their organizational potential. The importance of the university management in new economic conditions has risen manifold because, on the one hand, new decisions relate to the survival of the university in a market economy, and on the other hand-provide the foundation for the work in terms of innovative development of the economy.

We consider the organizational potential of the universities to be the basic element of a mechanism which 
enables to assess the possibility of the strategy implementation, its goals and objectives.

There are no scientific studies which enable a comprehensive approach to the assessment of the organizational potential of the universities. Only certain components of the organizational potential of the university are evaluated in the works of some authors (Znamenskiy \& Suychev, 2013; Pohlmann, 2009; Becker, 1993; Kravtsova \& Vasin, 2010; Palkin, 2008; Vasin \& Privalova, 2012), and this does not take into account the cumulative impact of all the factors on the effective functioning of the system, thus hampering the selection and adoption of the best managerial decisions.

As the foreign practice shows, the development and implementation of university teaching competency-based approach is possible with the use of elements of the Balanced Scorecard (Balanced Scorecard, BSC), which was developed by Harvard Business School professors Norton and Kaplan (Kaplan \& Norton, 1992). This system transforms the university mission and strategy into a set of operational objectives and work indicators. However, it has a number of drawbacks. In particular, the system of BSC provides a fixed set of directions, affecting the final efficiency; the proposed figures are ambiguous which makes the final use of the system complex.

In Russian practice the problem of choice of specific indicators for the monitoring of the chosen development strategy became complicated due to the implementation of the approximate list of criteria for evaluating the efficiency of higher education institutions by the Ministry of Education and Science (Implementation of the monitoring of the federal state institutions of high professional education, 2012). Educational, research, international, financial and economic activities of the organization of higher education are valued according to the list. Assessment methods based on the current list of Russian universities caused controversy in the Russian society due to the disagreement of the significant part of universities which underwent monitoring with the assessment of the obtained results.

This article is devoted to the solution of the most important managerial task namely the development of the assessment methods of the organizational potential of Russian universities.

\section{Materials and Methods}

Institutions of high education functioning in Penza region of the Russian Federation became the objects of research in the analytical and functional decomposition. As a methodological basis of research at different stages, depending on the nature of tasks, the method of system analysis was used. The methods of mathematical and multivariate statistics, factor analysis and benchmarking, as well as the method of questionnaire survey and expert estimates were applied in the course of the study.

We define the strategy of the university development as a system concept guiding and interconnecting the development of its activities with the long-term goals, which determine priority areas, forms of development, the nature of distribution and redistribution of resources, the sequence of phases of the long-term goals to provide the general strategy of the university development.

By the organizational potential we mean maximum possible ability of the university to optimize the functioning and interaction of the structural elements to achieve strategic goals and objectives.

At the same time the issues related to quantitative effectiveness of the processes occurring in the system of university management, and the need to transfer them into specific indicators become topical. This approach allows us to estimate the current level of development and identify existing reserves that means the potential development of the university.

It seems necessary to start the process of developing the methods for the organizational potential assessment with the composition and structure of the university potential. As we see it, the structure should compose 7 enlarged blocks: 1. human resources; 2. financial (economic) potential; 3. educational potential; 4. marketing potential; 5. international potential; 6 . research potential; 7. innovative potential.

Innovation potential is the basis for all the structural elements of the organizational potential of the university.

Included into each block components are integrated and interconnected, depending on the nature of the element in the system of the university.

For the development of the methods of the organizational potential efficiency it is necessary to make a list of indicators that might characterize each of the factors affecting the efficiency in the best way.

The structure of indicators is determined on the basis of analysis and generalization of the works by Russian and foreign authors, legal literature and analysis of management practices of the most successful foreign universities (University of Edinburgh, Thammasat, San Diego, etc.). While developing the indicators there were interviews with the interested parties and inquiry of the teacher's staff. 
In their development programs universities characterize the staff as permitting to prepare graduates demanded on the labor market, produce competitive scientific output both on the domestic and international markets.

For the integrated assessment of the personnel potential three mutually complementary evaluations are used as a rule: price, quality and quantity. Price assessment is based on the theory of "human resources" which emerged in the 60s of the last century. One of the brightest representatives of this theory is the American scientist Likert (Likert, 1967) (Table 1).

Table 1 . The list of indicators characterizing the human resources of the university

\begin{tabular}{ll}
\hline Designation & Indicator \\
\hline k1 & $\begin{array}{l}\text { Percentage of university faculty (UF) of doctors and/or professors, } \% \\
\text { k2 }\end{array}$ \\
k3 & $\begin{array}{l}\text { (full-time) } \% \\
\text { Percentage of Doctors of sciences under the age of } 50 \text { years of the total number of doctors }\end{array}$ \\
k4 & Percentage of UF teachers employed on a regular basis, $\%$ \\
k5 & Proportion of teachers with advanced training on the number of UF, $\%$ \\
k6 & Number of postgraduates per 100 students brought to full-time education, people. \\
k7 & Postgraduate efficiency percentage (quotient of thesis defence to the number of postgraduates ), \% \\
k8 & Doctorate efficiency percentage (number of defences to the number of issued theses), \% \\
\hline
\end{tabular}

Indicators characterizing the financial, educational, marketing, innovation, research and international potential of the university, are presented in Tables 2-7.

Table 2. The list of indicators characterizing the financial potential of the university

\begin{tabular}{ll}
\hline Designation & Indicator \\
\hline f1 & All sources income of high school per worker, thousand. \\
f2 & The share of income received in addition to budgetary funds from the Russian Ministry of \\
f3 & Education, \% \\
f3 & Share of administrative costs in the system of common academic expenses, $\%$ \\
f5 & The ratio of actual and planned financing, \% \\
& The proportion of the funds received from the sponsors on research activities, the total cost of \\
\hline
\end{tabular}

Table 3. The list of indicators characterizing the educational potential of the university

\begin{tabular}{|c|c|}
\hline Designation & Indicator \\
\hline $\mathrm{S} 1$ & $\begin{array}{l}\text { The percentage of students enrolled in educational programs of higher education that have } \\
\text { international accreditation, } \%\end{array}$ \\
\hline $\mathrm{S} 2$ & $\begin{array}{l}\text { The percentage of students enrolled in educational programs HPE receiving presidential } \\
\text { scholarship, the Russian Government scholarships, personal scholarships, established by } \\
\text { regulatory legal acts of the Russian Federation, } \%\end{array}$ \\
\hline $\mathrm{S} 3$ & $\begin{array}{l}\text { The proportion of graduates employed within one year after graduation on the acquired in the } \\
\text { course of study qualification on educational programs HPE, } \%\end{array}$ \\
\hline S4 & The percentage of the magistrates enrolled in master's programs, the total number of students, $\%$ \\
\hline S5 & $\begin{array}{l}\text { The percentage of students enrolled in the contracts with enterprises and organizations, total } \\
\text { number of the above contingent of students, } \%\end{array}$ \\
\hline S6 & $\begin{array}{l}\text { The percentage of students enrolled in the program of applied bachelor degree, the total number of } \\
\text { students, } \%\end{array}$ \\
\hline
\end{tabular}


Table 4. The list of indicators characterizing the research potential of the university

\begin{tabular}{|c|c|}
\hline Designation & Indicator \\
\hline n1 & The ratio of R \& D financed from external sources to total R \& D funding by one PPP), $\%$ \\
\hline $\mathrm{n} 2$ & The number of articles published in peer-reviewed journals for 100 people. PPP units. \\
\hline n3 & $\begin{array}{l}\text { The number of textbooks and teaching aids (stamped), published during the last five years, per } \\
100 \text { major staff with academic degrees and titles, units. }\end{array}$ \\
\hline $\mathrm{n} 4$ & The number of citations in RISC per 1 scientific pedagogical worker, unit. \\
\hline n5 & The number of citations in Web of Science on 1 scientific pedagogical worker, unit. \\
\hline n6 & The number of citations in Scopus per 1 scientific pedagogical worker, unit. \\
\hline $\mathrm{n} 7$ & $\begin{array}{l}\text { The share of expenditure on research and development (R \& D ) of the total expenditure of the } \\
\text { university, \% }\end{array}$ \\
\hline n8 & The share of revenues from $\mathrm{R} \& \mathrm{D}$ in the total income of the university \\
\hline n9 & $\begin{array}{l}\text { Revenues from university } \mathrm{R} \& \mathrm{D} \text { funds from private or commercial enterprises of mixed } \\
\text { ownership registered in the Russian Federation, on scientific and teaching staff, thous. }\end{array}$ \\
\hline $\mathrm{n} 10$ & $\begin{array}{l}\text { The ratio of income from sales of university organizations and its innovative infrastructure of } \\
\text { scientific and technical products, including the rights of intellectual property, federal budget } \\
\text { expenditures on R \& D performed by high school, \% }\end{array}$ \\
\hline
\end{tabular}

Table 5. The list of indicators characterizing the international potential of the university

\begin{tabular}{|c|c|}
\hline Designation & Indicator \\
\hline $\mathrm{m} 1$ & $\begin{array}{l}\text { The share of foreign students in the total number of students enrolled in educational programs } \\
\text { HPE full cost reimbursement, } \%\end{array}$ \\
\hline $\mathrm{m} 2$ & $\begin{array}{l}\text { The volume of } \mathrm{R} \& \mathrm{D} \text { funds received as a result of work on international and foreign grants, } \\
\text { contracts with non-resident organizations, thous. }\end{array}$ \\
\hline $\mathrm{m} 3$ & $\begin{array}{l}\text { Number of academic staff who have received international grants and prizes, global and national } \\
\text { awards, units. }\end{array}$ \\
\hline $\mathrm{m} 4$ & $\begin{array}{l}\text { The share of foreign postgraduate students with full reimbursement of the total number of } \\
\text { students graduate, } \%\end{array}$ \\
\hline $\mathrm{m} 5$ & $\begin{array}{l}\text { Number of full-time academic staff of the university who are leading research and teaching } \\
\text { activities in universities abroad, ed. }\end{array}$ \\
\hline $\mathrm{m} 6$ & $\begin{array}{l}\text { The share of scientific and pedagogical workers with a diploma or degree from foreign } \\
\text { universities, units. }\end{array}$ \\
\hline
\end{tabular}

Table 6 . The list of indicators characterizing the marketing potential of the university

\begin{tabular}{ll}
\hline Designation & Indicator \\
\hline $\mathrm{mk} 1$ & Brand recognition of the university \\
$\mathrm{mk} 2$ & The uniqueness of the university from a consumer perspective \\
$\mathrm{mk} 3$ & Optimality of educational services from the perspective of compliance with market demands \\
$\mathrm{mk} 4$ & Acceptable level of prices on services \\
$\mathrm{mk} 5$ & Teachers' qualification \\
$\mathrm{mk} 6$ & The extent of use of public relations \\
$\mathrm{mk} 7$ & Marketing tools flexibility \\
\hline
\end{tabular}

Table 7. The list of the indicators characterizing the innovative potential of the university

\begin{tabular}{ll}
\hline Designation & Indicator \\
\hline i1 & $\begin{array}{l}\text { Financial flows per year, passing through specialized units outside the standard of the educational } \\
\text { structure, the crucial task of bringing innovative ideas to industrial development, in relation to the } \\
\text { annual budget of the university, } \%\end{array}$ \\
i2 & $\begin{array}{l}\text { Percentage of the educational programs related to the total number of educational programs, } \% \\
\text { i3 }\end{array}$ \\
\hline
\end{tabular}


Direct measurement of the innovative potential of the university should cover the total financial income of the graduates (for a certain period, for example five years) and income of the university from its own scientific and innovative activity (for the same period), attributed to the total investment in the educational process and innovative scientific activity (for the same period). However, these measurements require the creation of the verified monitoring of the graduates success, allowing it to conduct the effective evaluation.

As the organizational potential of the university-is a complex multidimensional category which is characterized by a great number of particular indicators that can be qualitatively incomparable, it is reasonable to use multidimensional statistical methods that allow to quantify multi-featured objects for its assessment (Sazhin \& Saraikin, 2012).

The extent of "distance" from the reference or "proximity" to the worst value is determined by the complex index calculation, which is a function of the compared values, similar to that of the distance between the points in the multidimensional space. Multidimensional statistics methods help to obtain single expression characteristics of the non-uniformly scaled multidimensional phenomena preserving difference measures inherent to real values of parameters.

We suggest a five-point scale for each of the analyzed indicators referring to the following scoring system for assessment of the marketing potential: 0.1-0.2-"indicator has the worst lowest level"; 0.3-0.4-"indicator is low", 0.5-0.6-"indicator has an average level "; 0.7-0.8-"indicator is above the average level"; 0.9-1-"indicator has the best value". In this case it is possible to use the questionnaire method, where students, teachers, public representatives can serve as the respondents.

In order to obtain adequate results we suggest conducting comparison of the universities, united on the territorial basis, for example, a particular region or a federal district.

After the selection of the initial characteristics of the estimated object a choice of model indicators as well as the efficiency of the particular indicators characterizing the organizational potential of the university is carried out.

At the next stage while designing the integrated indicator the problem of the function choice turns up. It allows to get a set of separate indexes out of an integrated one. We propose to use the following model as the function:

$$
I=\sum_{i=1}^{n} \tilde{x}_{i} w_{i}
$$

where $\tilde{x}_{i}$-is the normalized value of the corresponding index;

$\widetilde{w}_{i}$-weight of the corresponding index;

i-ordinal number of the private-factor index;

n-number of factors used.

$$
\tilde{x}_{i}=\frac{x_{j-X_{j}}^{\min }}{x_{j}^{\max }-x_{j}^{\min }}
$$

where ${ }^{x_{j}}$ - the actual value of the factor for the tested university;

$x_{j}^{\min }$ and $x_{j}^{\max }$ - respectively the minimum and maximum value of this factor among the tested universities over the period.

For each of the seven blocks of the organizational potential of the university, private integral index was designed, and the value of the integral index of the composite will be the arithmetic mean value of the private block of indicators. 


$$
I_{\text {cons }}=\sum_{i=1}^{n} I_{i}
$$

The weighting factors in this study were calculated as a result of correlation and regression analysis of the impact of the proposed factors on the productive efficiency of the university-disposable income (profit) as $\%$ of net income.

The objects of the research were 15 higher education institutions operating in the Penza region of the Russian Federation.

\section{Results}

Thus, we obtain the following algorithm of the organizational potential assessment of the institution of high education:

Step 1: Identification of the factors affecting the efficiency of the institution of high education;

Step 2: Inventory of indicators that describe each of the factors affecting the efficiency in the best way;

Step 3: Selection of leading indicator values;

Step 4: Formation models-standard;

Step 5: Calculation of weighting coefficients;

Step 6: Estimation of the block integral indicators;

Step 7: Estimation of the integral composite index;

Step 8: Summarizing conclusions about the effectiveness of management with either form of the university potential in order to improve low levels indexes and reveal the prospects of the further development.

In the course of the analysis we have identified the main drawbacks of the assessment methodology of higher education institutions developed by the Ministry of Education and Science, which include the following points.

1) This technique does not allow to take into account sectoral and territorial affiliation of the universities.

2) It considers the activities of the universities in statics, does not allow to assess the ability of educational institutions to development at different initial stages.

3) The main part of the proposed indicators are not the factors of efficiency rating of educational activities in view of the existing methodological complexity of measuring the results of their activity and their correlation with further costs of educational services.

4) A part of the proposed indicators namely reflecting the structure of the student contingent, as well as characterizing the international activity of the university reflect the efficiency of the relevant ministry and not the university.

5) To assess the research activities of the universities the indicators which do not consider the results of studies published in monographs, collected papers of various authors, etc. are proposed, that in its turn leads to inadequate assessment of Russian scientists' research activities.

6) Unequal opportunities of the humanities and natural-science researches are not considered and the latter for several reasons will always be more efficient than the former.

7) Absolute not relative figures were accepted as the indicators of the financial and economic efficiency and consequently they do not give a proper assessment of the efficiency.

8) There is a problem of identification of the boundary characteristics of the selected indicators and of divergence of the normative and actual indicators analysis.

9) The implementation of this technique is framed by a certain university and it does not allow a comparative description in respect of other institutions of high education.

In the selection of the factors we tried as far as possible to neutralize the identified deficiencies.

The most difficult aspect of the construction of integral indices is retrieval of the weight coefficients. We reckon that the most preferable in this connection, is factor analysis, namely, correlation and regression analysis, which will highlight the factors that have the greatest influence on a certain kind of potential in the structure of the university potential. Unlike, the method of the analytical hierarchy, which is often used for calculating the weighting factors, factor analysis will neutralize the high level of subjectivity inherent to these methods. 
For quantitative assessment the closeness of the connection between the indicators used the correlation coefficient (r).

For qualitative assessment the closeness of the connection used the Cheddok's scale (Table 8).

Table 8 . The characteristic of connection between indicators

\begin{tabular}{lllllll}
\hline The index of closeness connection & $0.1-0.3$ & $0.3-0.5$ & $0.5-0.7$ & $0.7-0.8$ & $0.9-0.99$ & 1 \\
\hline The characteristic of connection & weak & moderate & noticeable & tight & Very tight & functional \\
\hline
\end{tabular}

To test the significance of the coefficient found checking for significance using Student's $t$ test.

The data on the presence of moderate, noticeable and the tight connection between indicators evaluation of human resources, financial, educational, research, marketing, innovative and international potential of higher education and outcome indicator of the university-available income (profit) as \% of net income, are presented in Table 9.

Table 9. The characteristic of connection between indicators

\begin{tabular}{|c|c|c|c|}
\hline Indicators & $r$ & $r^{2}$ & $\begin{array}{l}\text { The characteristic of } \\
\text { connection }\end{array}$ \\
\hline Percentage of university faculty (UF) of doctors and/or professors, $\%$ & 0.6611 & 0.4371 & noticeable \\
\hline $\begin{array}{l}\text { Percentage of Doctors of sciences under the age of } 50 \text { years of the } \\
\text { total number of doctors (full-time), \% }\end{array}$ & 0.7241 & 0.5243 & tight \\
\hline $\begin{array}{l}\text { Proportion of teachers with advanced training on the number of } \\
\text { UF, \% }\end{array}$ & 0.3047 & 0.0928 & moderate \\
\hline $\begin{array}{l}\text { The share of income received in addition to budgetary funds from the } \\
\text { Russian Ministry of Education, \% }\end{array}$ & 0.6304 & 0.3974 & noticeable \\
\hline $\begin{array}{l}\text { Share of administrative costs in the system of common academic } \\
\text { expenses, } \%\end{array}$ & 0.7117 & 0.5065 & tight \\
\hline $\begin{array}{l}\text { The ratio of } R \& D \text { financed from external sources to total } R \& D \\
\text { funding by one PPP), } \%\end{array}$ & 0.3282 & 0.1077 & moderate \\
\hline $\begin{array}{l}\text { The number of articles published in peer-reviewed journals for } 100 \\
\text { people. PPP units. }\end{array}$ & 0.4891 & 0.2392 & moderate \\
\hline $\begin{array}{l}\text { The number of textbooks and teaching aids (stamped), published } \\
\text { during the last five years, per } 100 \text { major staff with academic degrees } \\
\text { and titles, units. }\end{array}$ & 0.4346 & 0.1889 & moderate \\
\hline $\begin{array}{l}\text { The number of citations in RISC per } 1 \text { scientific pedagogical worker, } \\
\text { unit. }\end{array}$ & 0.3048 & 0.0929 & moderate \\
\hline $\begin{array}{l}\text { The number of citations in Scopus per } 1 \text { scientific pedagogical } \\
\text { worker, unit. }\end{array}$ & 0.4675 & 0.2186 & moderate \\
\hline $\begin{array}{l}\text { The share of expenditure on research and development (R \& D ) of } \\
\text { the total expenditure of the university, } \%\end{array}$ & 0.7954 & 0.6327 & tight \\
\hline $\begin{array}{l}\text { The share of revenues from } \mathrm{R} \& \mathrm{D} \text { in the total income of the } \\
\text { university }\end{array}$ & 0.3875 & 0.1502 & moderate \\
\hline Brand recognition of the university & 0.5418 & 0.2935 & noticeable \\
\hline The uniqueness of the university from a consumer perspective & 0.4516 & 0.204 & moderate \\
\hline $\begin{array}{l}\text { Optimality of educational services from the perspective of } \\
\text { compliance with market demands }\end{array}$ & 0.3815 & 0.1455 & moderate \\
\hline Teachers' qualification & 0.7611 & 0.5793 & tight \\
\hline The extent of use of public relations & 0.5948 & 0.3502 & noticeable \\
\hline
\end{tabular}

Thus, for example, the value of the correlation coefficient characterizing the closeness of the relationship between the share of administrative costs in the system of general academic expenses and outcome 
indicator-available income (profit) institution of higher education, was 0.7117 , which means that there is a tight connection between the factor and result.

The significance of the coefficient found confirmed Student's test, which exceeds the value for confidence level of 0.95 .

The coefficient of determination $\left(\mathrm{r}^{2}\right)$ is 0.5065 and indicates that $50.65 \%$ of the variation is determined by changes in the effective index of this factor.

The analysis of the results of the calculations showed that the greatest contribution to the development of the institutional capacity of the university is carried by the following factors:

1) Percentage of the faculty (PPP) doctors and/or professors, \% (correlation coefficient was 0.6611 );

2) Percentage of Doctors of sciences under the age of 50 years the total number of doctors (full-time), $\%$ (correlation coefficient was 0.7241 );

3) The share of income received in addition to public funds from the Russian Ministry of Education, \% (correlation coefficient was 0.6304);

4) Share of administrative costs in the common academic expenses, \% (correlation coefficient was 0.7117 );

5) The share of expenditure on research and development (R\&D) of the total expenditure of the university, \% (correlation coefficient was 0.7954 );

6) Teachers' qualification (the correlation coefficient was 0.7611 );

7) Brand recognition of the university (correlation coefficient was 0.5418 );

8) Public relations (correlation coefficient was 0.5948).

Graphical representation of the composite integral indicator of organizational capacity of one of the studied higher education institutions represented in the following figure (Figure 1).

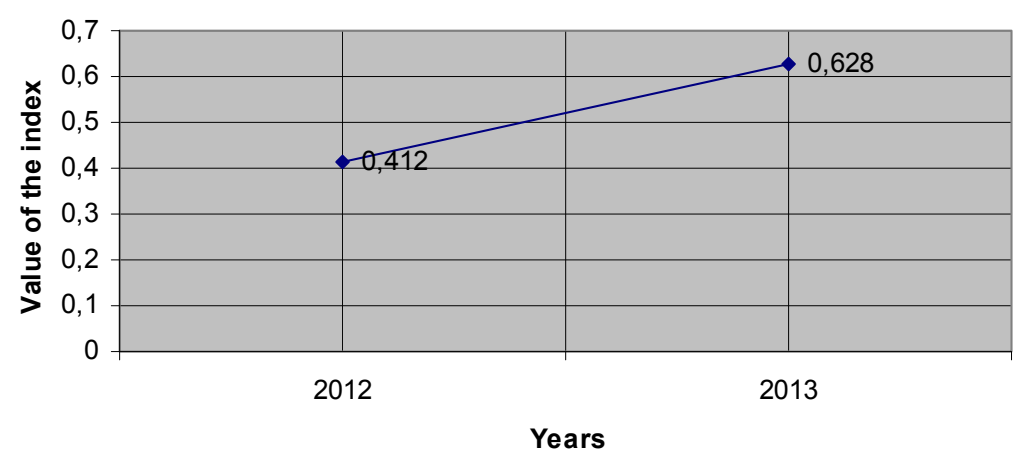

Figure 1. Dynamics of composite integral index of one of the analyzed universities

Thus, an integral component in this case is a positive trend, due, primarily, by the measures being taken by the government over the last few years on the development of science in Russia.

Calculation and construction of the integral index of the composite can not only reduce the number of different indicators into one, but also reveal the structure of institutional potential, which in turn makes it possible to draw conclusions on the contribution of a specific form of the potential in the overall result, as well as the weak development of a type of potential.

\section{Discussion}

The personnel potential of the university reflects not only the workers' qualification and ability to carry out their duties in the present time, but also their long term total potential-with reference to age, scientific and pedagogical qualifications, experience, business activity, quality of activity (including the impact), practical experience, business activity and innovative skills, level of motivation. This idea of the personnel potential should be adopted as one of the central objects of the university management and in the system of higher education as a whole.

Evaluation of the university financial potential-is one of the most difficult stages in terms of the reforms in the system of higher education, which involves identification of financial maintenance and development, including 
non-budget ones, aimed at strengthening the economic independence on condition of the university restructuring, improving the quality of education services, introduction of the principles of efficiency of public expenditure on higher education.

By research potential of higher education we mean the ability and opportunity to conduct the basic and applied research and experimental-design activities, enabling the preparation of the highly qualified specialists and creation of conditions for the formation of new business structures both in Russia and abroad.

A research institution of higher education should focus on constant improvement of highly qualified specialists' training and increase of the number of new technologies in the process of innovative research and their transfer to the business sector of the economy and the social sphere.

In modern conditions the universities become subjects of globalization, creating and implementing strategies that enable to manage and control the processes of internationalization through the integration of the international, intercultural and global dimension into all the aspects of the university activity [10]. A comparison of the university rating enhances their status and increases competition. In the ranking of The Times Higher Education World University Ranking 2013-2014 the top 400, namely, the group of 226-250, only one institution of Russia got it-Lomonosov Moscow State University (Times Higher Education, 2014).

According to the authors (Emelianov, 2007; Yrinen \& Petola, 2006; Kirby, 2006) the innovative potential of universities is a system of interconnected and interacting innovative resources of universities necessary in the process of innovation related to their limited nature and possible (positive or negative) impact on the final result of their activity, as well as a factor of competitive advantages of the higher school, its innovative investment attractiveness.

The need to develop innovative potential of higher education is associated with a number of recent trends, including the modernization and diversification of the economy, aggravation of competition in the knowledge and technology markets, awareness of the new role of universities not only as centers of advanced science and education, but also as the most important objects of the innovative activity focused on the commercialization of scientific and technological activities through the withdrawal of science intensive competitive products; the growing number of universities, as well as an imbalance of supply and demand structure in the education market.

Marketing potential of the university is of special significance in a market economy. Marketing strategy, which is selected by the university, is aimed at strategic action identification in the field of improving the competitiveness in search of competitive advantages in the markets of high school educational services and labor, ensuring effective internal and external communications, training and strengthening of a positive university image.

In the selection of the factors we have sought to neutralize the shortcomings identified in the analysis methodology developed by the Ministry of Education and Science (Ministry of Education and Science of the Russian Federation, 2012).

Identifying key factors that have the greatest impact on the efficiency of the university as a subject of market relations, there is a possibility of a rational allocation of resources for its operation and development. Identified according must be periodically adjusted, is not particularly difficult, in contrast to other techniques, for example, methodology Data Envelopment Analysis (DEA), differing complexity and interpretation of results. First DEA method has been used in the U.S., and its underlying principles have been described in the article "Measuring the Efficiency of Decision Making Units" (Charnes et al., 1978; Cooper et al., 2000; Sowlati et al., 2004).

The basic idea of DEA model is that the effectiveness of any organization, including the university, can be represented as the ratio of the results to the resources used (as resources may make expenditures on scientific activities, or payroll and as a result-the number of graduates, Winners of the degrees of protection in this University, the number of publications and patents). As the construction of the ratings, it is assumed that each criterion has a weighting factor, which is defined in the model by solving the optimization problem.

Unlike Russia, the world practice DEA model has been widely used. Western scholars use different variations thereof. Often authors try to consider the structural differences between universities, colleges sharing aimed at scientific or educational activities.

For example, Jill Johnes analyzed the efficiency of British universities for the academic year, aiming to identify the structural differences between the three categories of schools: with the status of the university until 1992, got it after 1992 and colleges (Johnes, 2006). Although was not found significant differences between the categories of universities.

It should be noted that our proposed method is realizable in practice in the presence of a group of homogeneous, 
similarly functioning objects, which will enable to assess and compare the efficiency of operating of higher educational institutions on various criteria, such as territorial, the profile of activity or status. This technique allows the context of how to realize a sectoral approach.

Famous Scientists Antreas D. Athanassopoulos and Estelle Shale (1997) evaluated the 45 universities in England, using two approaches: based on the first evaluated the effectiveness of the distribution of the funding in existence, in the second-the quality use of available resources, that is, the number of students and teachers, the level of training of students, as well as budgetary expenditure on research projects, and library fund.

Necmi K. Avkiran (2001) evaluated the effectiveness of attracting paying students to study in Australian universities, as well as the overall efficiency and quality of teaching. This experience is interesting for Russia, because of reductions in state funding of higher education institutions.

An important aspect is that, unlike a number of techniques developed on the basis of the concept of European Foundation for Quality Management (EFQM), our proposed method is suitable for estimating the activity of the university not only as a social sector organization, but also as a socio-economic system as a whole (Maslov, 2008; Levshina et al., 2007).

The proposed method has much in common with the Greek experience in assessing the effectiveness of university-based work Katharakis G. and Katharaki M. (2010). For evaluation and ranking of the indicator used to build regression. According to the results, the authors conclude consistency models.

Thus, various methods are used extensively by Western scientists to evaluate the effectiveness of the system of higher education in various aspects, which cannot be said of the Russian practice. Russian universities, as actors of the market economy, become participants in the tough competition in the education market of the country. Unfortunately, these problems are almost never neglected, reducing the role of Russia in the world educational space and the loss of previously held positions in the world market.

Using our proposed methodology for assessing the effectiveness of universities is essential in today's conditions, as it will allow a comprehensive approach to the evaluation of university and reasonable management decisions.

\section{Conclusions}

The study developed the methods with the following characteristics:

Firstly, it provides the possibility of considering the institution of high education as a subject of market relations and the use of many factors that can be later supplemented in calculation;

Secondly, there is a possibility to take into account territorial characteristics of the regions in which universities operate when calculating the effectiveness of universities;

Thirdly, the technique allows not only to determine the level of private indicators characterizing the efficiency of organizational potential, but also to identify existing reserves of development, to identify key factors that have the greatest impact on the effectiveness of the university activities, united on a territorial basis, and to compare the objects of study.

The proposed methods will contribute to the accumulation of the organizational potential of the universities and the efficiency of their work.

The proposed methodology will contribute to the accumulation of organizational capacity of higher education institutions and improve the efficiency of their work.

However presented technique is limited by conditions of its application in practice:

1) Set of factors, and, moreover, their importance (weighting factors) will vary depending on the territorial entity where appropriate analysis is performed;

2) Input data set should be sufficient for a finding of weighting factors and identify patterns;

3) Revealed relations should be sufficiently stable for a certain period of time.

We present the following prospects of using the proposed method:

1) The development of mathematical models that reflect the influence of factors on productive performance of universities;

2) Using social performance of the university as output indicators;

3) Making forecasting results based on mathematical models, but only in the medium term. 


\section{References}

Athanassopoulos, A. D., \& Shale, E. (1997). Assessing the Comparative Efficiency of Higher Education Institutions in the UK by the Means of Data Envelopment Analysis. Education Economics, 5, 117-134. http://dx.doi.org/10.1080/09645299700000011

Avkiran, N. K. (2001). Investigating technical and scale efficiencies of Australian Universities through data envelopment analysis. Socio-Economic Planning Sciences, 35, 57-80. http://dx.doi.org/10.1016/S0038-0121 (00)00010-0

Becker, G. S. (1993). Human Capital: A theoretical and empirical analysis, with special reference to education (p. 412). Columbia University Press. http://dx.doi.org/10.7208/chicago/9780226041223.001.0001

Charnes, A. et al. (1978). Measuring the Efficiency of Decision Making Units. European Journal of Operational Research, 2, 427-447. http://dx.doi.org/10.1016/0377-2217(78)90138-8

Cooper, W. W. et al. (2000). Data Envelopment Analysis: A Comprehensive Text with Models, Applications, References (p. 318). Kluwer Academic Publishers.

Emelianov, S. G. (2007). The economic mechanism of the strategic management development of the university (p. 210). Moscow.

Goelli, T. et al. (1998). An Introduction to Efficiency and Productivity Analysis (p. 275). Kluwer Academic Publishers.

Johnes, J. (2006). Data Envelopment Analysis and its Application to the Measurement of Efficiency in Higher Education. Economics of Education Review, 25, 273-288. http://dx.doi.org/10.1016/j.econedurev.2005. 02.005

Kaplan, R. S., \& Norton, D. P. (1992). The Balanced Scorecard-Measures that Drive Performance (p. 79). Boston: Harvard Business School Press.

Katharakis, G., \& Katharaki, M. (2010). A comparative assessment of Greek universities' efficiency using quantitative analysis. International Journal of Educational Research, 49, 115-128. http://dx.doi.org/10.1016 /j.ijer.2010.11.001

Kirby, D. A. (2006). Creating Entrepreneurial Universities in the UK: Applying Entrepreneurial Theory to Practice. Journal of Technology Transfer, 31, 599-603. http://dx.doi.org/10.1007/s10961-006-9061-4

Kravtsova, V. I., \& Vasin, V. A. (2010). The university potential for the post crisis development in Russia. Systems engineering. Retrieved March 28, 2014, from http://www. systech.miem.edu.ru

Levshina, V. V. et al. (2007). Rating effectiveness Quality Management System of educational organization. Problems of the modern economy, 23, 18-24.

Likert, R. (1967). Human Organization: Its Management and Value (p. 258). McGraw-Hill.

Maslov, D. V. (2008). From quality to perfection. Useful model EFQM. Standards and Quality, 152.

Order of Ministry of educational and science of Russian Federation "Implementation of the monitoring of the federal state institutions of high professional education" of 3.08.2012. Volume 5583.

Palkin, E. A. (2008). Innovation indicators. Accreditation in education, 26, 54-55.

Peter, T. K., \& Yorke, M. (2003). Assessment. Learning and Employability (p. 245). McGraw-Hill International.

Pohlmann, T. (2009). Innovationspotenziale und-verwertungsstrategien an deutchen Hochschulen. Marburg: Discussion Papers on Strategy and Innovation, 51.

Sazhin, Y. V., \& Saraikin, Y. V. (2012). The application of the multivariate analysis conformity for the structural analysis of the pedagogical staff of the research university. Vestnik NSUEM, 3, 121-131.

Solwati, T. et al. (2004). Establishing the "practical frontier" in data envelopment analysis. Omega, 32, 261-272. http://dx.doi.org/10.1016/j.omega.2003.11.005

Times Higher Education: Official website. Retrieved March 28, 2014, from http://www.timeshighereducation. co.uk/

Vasin, S. M., \& Privalova, I. N. (2012). The university affiliate specificity management (Vol. 28, pp. 275-280). Izvestia Penza state pedagogical university named after Belinsky V.G.

Yrinen, M. H., \& Petola, U. (2006). The problems of market-oriented University. Higher Education, 52, 251-281. 
http://dx.doi.org/10.1007/s10734-004-2749-1

Znamenskiy, D. Y., \& Suychev, A. V. (2013). Scientific potential of private high school organization: System approach to it is research. Naukovedenie, 4. Retrieved March 28, 2014, from http://www.naukovedenie.ru /PDF/09evn413.pdf

\section{Copyrights}

Copyright for this article is retained by the author(s), with first publication rights granted to the journal.

This is an open-access article distributed under the terms and conditions of the Creative Commons Attribution license (http://creativecommons.org/licenses/by/3.0/). 